\title{
Glucose Metabolism in Pancreatic Cancer
}

\author{
Liang Yan ${ }^{1}\left(\mathbb{D}\right.$, Priyank Raj $^{1}$, Wantong Yao ${ }^{2}$ and Haoqiang Ying ${ }^{1, *(D)}$ \\ 1 Department of Molecular and Cellular Oncology, University of Texas MD Anderson Cancer Center, Houston, \\ TX 77030, USA; yliang4@mdanderson.org (L.Y.); praj@mdanderson.org (P.R.) \\ 2 Department of Translational Molecular Pathology, University of Texas MD Anderson Cancer Center, \\ Houston, TX 77030, USA; wyao2@mdanderson.org \\ * Correspondence: hying@MDANDERSON.ORG
}

Received: 12 August 2019; Accepted: 25 September 2019; Published: 29 September 2019

check for updates

\begin{abstract}
Pancreatic ductal adenocarcinoma (PDAC) is one of the most aggressive and lethal cancers, with a five-year survival rate of around $5 \%$ to $8 \%$. To date, very few available drugs have been successfully used to treat PDAC due to the poor understanding of the tumor-specific features. One of the hallmarks of pancreatic cancer cells is the deregulated cellular energetics characterized by the "Warburg effect". It has been known for decades that cancer cells have a dramatically increased glycolytic flux even in the presence of oxygen and normal mitochondrial function. Glycolytic flux is the central carbon metabolism process in all cells, which not only produces adenosine triphosphate (ATP) but also provides biomass for anabolic processes that support cell proliferation. Expression levels of glucose transporters and rate-limiting enzymes regulate the rate of glycolytic flux. Intermediates that branch out from glycolysis are responsible for redox homeostasis, glycosylation, and biosynthesis. Beyond enhanced glycolytic flux, pancreatic cancer cells activate nutrient salvage pathways, which includes autophagy and micropinocytosis, from which the generated sugars, amino acids, and fatty acids are used to buffer the stresses induced by nutrient deprivation. Further, PDAC is characterized by extensive metabolic crosstalk between tumor cells and cells in the tumor microenvironment (TME). In this review, we will give an overview on recent progresses made in understanding glucose metabolism-related deregulations in PDAC.
\end{abstract}

Keywords: glucose metabolism; pancreatic cancer

\section{Introduction}

Pancreatic ductal adenocarcinoma (PDAC) is one of the most aggressive solid malignancies, which is projected to soon become the second leading cause of cancer-related deaths in the US [1]. Oncogenic Kirsten rat sarcoma 2 viral oncogene homolog (KRAS) mutations, which occur in over 90\% of human PDAC, are the dominant driver for tumor progression and play a critical role in reprogramming metabolism [2]. It has been known for almost a century that cancer cells take up enormous amounts of glucose, which is fermented to produce lactate even in the presence of oxygen, a process described as the Warburg effect. The development of various sophisticated analytic tools, including mass spectrometry- or nuclear magnetic resonance-based (NMR-based) metabolomic analysis, isotype-labeled nutrient tracing, and hyperpolarized magnetic resonance metabolic imaging in patients and preclinical models, has greatly enhanced the comprehensive and in-depth characterization of tumor metabolism programs. As a result, the reprogramming of metabolic pathways, including enhanced glycolysis, has been recognized as one of the emerging hallmarks of cancer [3]. Glycolysis is the central carbon metabolism pathway in cells, which provides energy in the form of ATP and also fuels cell growth and division by providing biomass. Importantly, there are several critical metabolic pathways that branch from glycolysis, including the pentose phosphate pathway (PPP), hexosamine biosynthesis 
pathway (HBP), serine biosynthesis, and tricarboxylic acid cycle (TCA cycle). These branched pathways have been proven to work together or individually to promote tumorigenesis.

The critical role of reprogramed metabolism has been well characterized in PDAC tumorigenesis. KRAS mutation in PDAC can enhance the glycolytic pathway by upregulating the expression of glucose transporters and rate-limiting enzymes of glycolysis, such as hexokinase 2 (HK2), phosphofructokinase-1 (PFK1), and lactate dehydrogenase A (LDHA) [2,4]. The enhanced glucose metabolism can promote PDAC tumorigenesis by providing energy (glycolytic flux and TCA cycle), new biomass support (PPP and serine biosynthesis pathway), reactive oxygen species (ROS) maintenance (glutamine metabolism and TCA cycle), signal modulation (HBP), and DNA methylation (serine biosynthesis pathway). In addition, oncogenic KRAS also reprograms the glutamine metabolism to support the redox homeostasis of PDAC [5]. Furthermore, a broad metabolite profiling analysis characterized three different metabolic subtypes of PDAC, including the slow proliferating, glycolytic, and lipogenic subtype. Lipogenic PDAC tumors are associated with the epithelial phenotype, whereas the glycolytic subtype was related to the mesenchymal phenotype. Notably, different subtypes of PDAC classified on the basis of their metabolic profile show distinct sensitivities to metabolic inhibitors, which illustrates the metabolic heterogeneity of PDAC [6]. In addition, cancer cells can enhance salvage pathways, such as autophagy [7] and macropinocytosis [8,9], to further scavenge essential metabolites to support its fast division or proliferation. Accumulating evidence has established that the metabolic reprogramming in the tumor environment is also critical for PDAC tumorigenesis. Metabolites released from stromal cells can be taken up by cancer cells to support tumor growth or may be used to generate resistance to drugs $[10,11]$. The translational potential of targeting metabolism pathways for cancer treatment has been nicely reviewed recently [12]. Here, we will provide a broad description of the molecular mechanisms underlying the glucose metabolism reprogramming in PDAC.

\section{Activation of Glycolysis in PDAC}

Altered glycolysis has been recognized as the major metabolic alteration in pancreatic cancer. The glycolytic flux in cancers is tightly controlled to meet the fast proliferative needs, as well as to provide building blocks for synthetic reactions. As such, many glycolytic enzymes are associated with poor prognosis of PDAC. Genetic or pharmacological inhibition of key glycolytic genes, such as HK2, PFK1, and LDHA, has been shown to inhibit the tumorigenic activity of PDAC cells. Here, we will focus on the mechanisms that maintain a high glycolysis rate in PDAC (Figure 1).

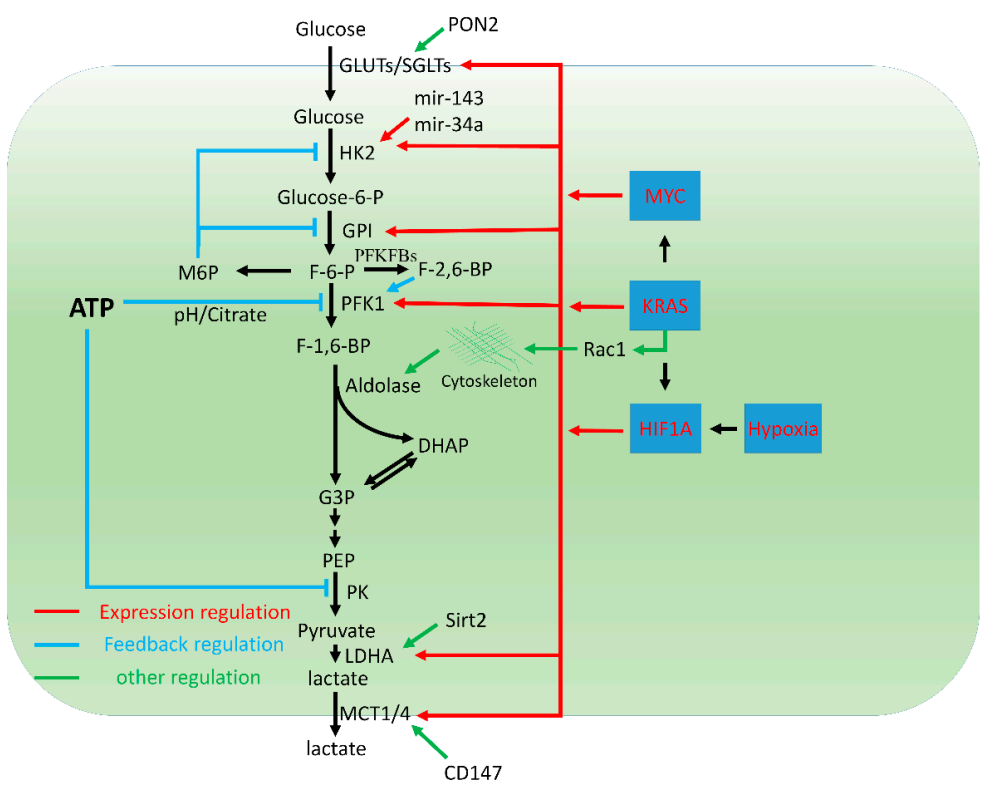

Figure 1. Regulation of glycolysis in PDAC. 


\subsection{Enhanced Glucose Uptake}

The transport of glucose across the plasma membrane is one of the rate-limiting steps and is mediated by two classes of glucose transporters, including facilitated transporters (GLUTs) and active transporters or symporters (SGLTs). Facilitative GLUTs enable the ATP-independent transportation of glucose across a hydrophobic cell membrane, down its concentration gradient. Among the GLUTs, expression of GLUT-1 (SLC2A1) is associated with PDAC progression. A progressive increase in the expression of GLUT-1 was observed from low-grade to higher-grade dysplastic lesions, with no expression in the acini or ducts in normal pancreas and detectable expression in $74 \%$ of cases [13], which may be due to the activation of mutant KRAS [2]. The increased expression of GLUT-1 in human pancreatic tumors was also suggested by the higher rate of 18F-FDG uptake into tumor cells compared with normal pancreatic tissue [14,15]. In addition, a direct correlation was observed between GLUT-1 expression and histological grade or tumor size in PDAC patients [13]. Patients with low expression of GLUT-1 in the primary tumor have a better prognosis and therapeutic response to neoadjuvant chemoradiotherapy compared with those with high GLUT-1 expression [16], underscoring the role of GLUT-1 in PDAC malignancy. Besides the transcriptional regulation, it has been shown that Paraoxonase 2 (PON2) directly interacts with GLUT-1 to stimulate glucose uptake and therefore promote PDAC tumor growth [17]. Interestingly, PON2 increased glucose uptake via mediation of the interaction of stomatin and GLUT1 rather than transcriptional or translational regulation of GLUTs or HK2.

In additional to GLUTs, a recent study has indicated that PDAC also overexpresses an alternative glucose transporter, SGLT2 (SLC5A2), which is normally expressed in the kidney, and mediates sodium-dependent glucose reabsorption $[18,19]$. Treating PDAC xenograft models with canagliflozin, a SGLT2 inhibitor used for type 2 diabetes, not only inhibited tumor growth but also sensitized tumors to PI3K inhibitor $[19,20]$. However, it remains to be further investigated whether the anti-tumor response of canagliflozin is due to the direct impact on tumor cell SGLT2 or systematic effect on the blockade of feed-back insulin induction.

\subsection{Feedback Regulation of Glycolysis}

There are a total of 10 steps in glycolytic process linking extracellular glucose to excreted lactate, of which three steps catalyzed by hexokinase, phosphofructokinase, and pyruvate kinase are virtually irreversible and are believed to be the regulatory sites in the glycolytic flux. Among them, phosphofructokinase (PFK), which catalyzes the rate-limiting phosphorylation of fructose-6-phosphate to fructose-1,6-bisphosphate, serves as the gatekeeper for mammalian glycolysis and is subjected to allosteric inhibition by ATP. The inhibitory effect of ATP is further potentiated by a decrease in $\mathrm{pH}$ [21]. To maintain glycolysis at a high rate, cancer cells need to maintain the homeostasis of intra-cellular $\mathrm{pH}$ levels by actively transporting lactate into the extracellular space. Indeed, monocarboxylate transporter 1 (MCT1) and monocarboxylate transporter 4 (MCT4), two major lactate transporters, are robustly expressed in PDAC cells [22]. KRAS signaling has been shown to induce the expression of MCT4 to promote lactate efflux and thus mitigate the toxic effects of intracellular lactate accumulation due to elevated glycolysis [23]. Besides the $\mathrm{pH}$ regulation, export of lactate will promote the reduction of pyruvate to lactate and oxidation of nicotinamide adenine dinucleotide (NADH) to NAD+. Importantly, the generated NAD+ is an essential coenzyme for the oxidation of glyceraldehyde 3-phosphate and maintenance of continued glycolysis. In addition, the membrane localization of MCT1 and MCT4 has been shown to be facilitated by cluster of differentiation 147 (CD147), a glycoprotein highly expressed in PDAC [24,25]. CD147 depletion results in the accumulation of lactate in tumor cells and suppressed PDAC growth in xenograft models [26]. Moreover, a recent study indicated that lactate may also be dissipated through gap junctions besides the exportation through lactate transporters [27].

Another factor that augments the inhibitory effect of ATP on phosphofructokinase is citrate, an intermediate of the TCA cycle [28]. Citrate is exported out of mitochondria and utilized by ATP-citrate lyase (ACLY) for the maintenance of the cytosolic acetyl coenzyme A (acetyl-CoA) pool. 
Therefore, enhanced ACLY activity in tumor cells serves to avoid the accumulation of citrate to ensure glycolysis flux and cell proliferation. Indeed, ACLY-dependent metabolism is elevated during PDAC development, and deletion of ACLY suppressed tumor growth [29]. Interestingly, while ACLY depletion leads to inhibition of glycolysis as expected, citrate is not elevated, at least in ACLY knockout adipocytes, implicating additional mechanisms for the regulation of glycolysis [30].

Besides the regulation through allosteric inhibition, the activity of PFK is also tightly controlled by its allosteric activator, fructose 2,6-bisphosphate, whose metabolism is mediated by the family of bifunctional enzymes 6-phosphofructo-2-kinase/fructose 2,6-bisphosphatases (PFKFBs). Among them, PFKFB3 is regarded as the major player contributing to elevated glycolysis in tumor cells due to its unique high kinase/phosphatase activity ratio and the inducible nature of this gene under hypoxia and inflammatory conditions [31-33]. Indeed, PFKFB3 is overexpressed in a variety of human cancers, including pancreatic cancer [34,35]. Moreover, PFKFB3 is required for RAS-induced cellular transformation [36], underscoring the importance of PFKFB3-mediated glycolysis regulation during tumor development.

Such feedback regulation of glycolysis has also been exploited for the inhibition of additional regulatory steps in glycolysis to target PDAC cells. A recent study showed that high mannose treatment leads to inhibition of tumor growth in mannose phosphate isomerase (MPI)-low pancreatic cancer cells [37]. MPI catalyzes the conversion between fructose-6-phosphate and mannose-6-phosphate and high dose mannose treatment in MPI-low cells leads to the accumulation of mannose-6-phosphate, which in turn shuts down glycolysis and suppresses tumor growth through the feedback inhibition of glycolytic enzymes hexokinase (HK) and phosphoglucose isomerase (PGI) [37,38].

\subsection{Transcriptional and Post-Transcriptional Control of Glycolysis}

The glycolytic activity in tumor cells is regulated in part by the expression of rate-limiting glycolytic genes. The major determinants for the expression level of glycolysis genes in PDAC include its driver oncogene and the tumor microenvironment. It is well known that oncogenic KRAS induces glycolysis and recent studies demonstrated that KRAS signaling plays a profound role in the transcription of glucose transporters and key glycolysis genes in tumor cells [2,39,40]. As a key dependence in KRAS-driven tumors, the MYC oncogene has been implicated in the induction of glycolysis genes downstream of KRAS signaling in PDAC cells [2,41-43]. One defining feature of human PDAC is its severely hypoxic microenvironment [44]. Under hypoxia, hypoxia-inducible factor (HIF1A) is stabilized and induces the expression of multiple genes involved in glycolysis [45,46]. Accordingly, HIF1A levels are upregulated in PDAC, and multiple glycolysis-related genes, including GLUT-1 and MCT4, are highly expressed in the hypoxic regions [47]. It should be noted that oncogenic KRAS can induce HIF1A in a PI3K-dependent manner independent of hypoxia [48,49]. How KRAS signaling may cooperate with hypoxia to induce glycolysis and the relationship between MYC-driven and HIF1A-driven expression of glycolysis genes in PDAC remain to be fully elucidated. Both MUC1 and MUC13 were reported to stabilize the HIF1 in PDAC, which subsequently enhances glucose metabolism by elevated expression of glycolysis enzymes [50-52]. While additional transcription factors, such as KLF4 and FOXM1, have also been reported to induce glycolysis in PDAC cells through the transcriptional upregulation of LDHA [53,54], their in vivo relevance needs to be further validated.

In addition, the expression of glycolysis genes is also regulated at the post-transcriptional level. BCL2 associated athanogene 3 (BAG3), a cochaperone protein, has been shown to stabilize HK2 mRNA and therefore induce HK2 expression to enhance glycolysis and tumorigenic activity in PDAC cells [55]. Accordingly, BAG3 is found to be overexpressed in PDAC and correlated with poor clinical outcome in patients [55,56]. HK2 expression is also negatively regulated by microRNA-143 (mir-143), a tumor suppressive microRNA (miRNA) [57,58]. Importantly, miR-143 expression has been shown to be silenced by oncogenic KRAS in PDAC cells [59]. In addition, miR-34a is another tumor suppressive miRNA likely involved in the glycolytic regulation in PDAC. MiR-34a, a downstream target of tumor suppressor p53, is downregulated in the majority of PDAC cells and its low expression is significantly 
correlated with the poor prognosis of PDAC patients $[60,61]$. Similar to miR-143, miR-34a has been implicated in the regulation of glycolysis genes, including HK1, HK2, GPI, and LDHA [62,63]. Therefore, driver mutations of PDAC, such as KRAS and TP53, are also involved in the post-transcriptional regulation of glycolysis.

Besides regulation at the expression level, multiple glycolysis genes are also modulated at the post-translational level in PDAC. Hypoxia has been shown to activate PFKFB3 through AMPK-dependent phosphorylation $[62,64]$. This is concordant with the critical role of AMPK for the adaptation of PDAC cells under conditions of metabolic stress [65]. Additionally, the deacetylase SIRT2 has been shown to be overexpressed in PDAC, which results in LDHA deacetylation and activation to promote glycolysis in tumor cells [66]. Moreover, tumor suppressor FBW7 has been shown to function as a negative regulator of glucose metabolism via the c-Myc/TXNIP axis in PDAC [67]. Interestingly, hyperactivation of RAS-RAF-MEK-ERK signaling decreases FBW7 expression in PDAC [68], indicating the role of FBW7 in KRAS-regulated glucose metabolism.

Lastly, a recent study demonstrated that PI3K-mediaiated Rac1 activation leads to the disruption of actin filaments, which mobilizes aldolase from the cytoskeleton and elevates the enzymatic activity of aldolase to increase glucose flux through glycolysis [69]. Notably, the PI3K-Rac1 axis plays a critical role for the cytoskeleton remodeling in PDAC and is required for KRAS-induced pancreatic tumorigenesis [70,71]. These studies implicate the important role of subcellular localization in the regulation of glycolytic enzyme activities in response to oncogenic signaling in PDAC.

In summary, the regulation of glycolysis in PDAC is largely achieved through epigenetic and post-transcriptional mechanisms. However, it does not exclude the possibility that alterations at the genetic level are also contributing to glycolysis activation in PDAC even though recurrent somatic alterations in glycolysis genes are rare in PDAC if not none. Indeed, single nucleotide polymorphisms in HK2 have been reported to be significantly associated with patient survival in PDAC [72], prompting the need to further validate the function of those gene variants and their involvement in metabolic regulation in PDAC.

\section{Enhanced Glucose Flux into Anabolic Pathways}

\subsection{Pentosephosphate Pathway (PPP)}

The PPP is composed of two arms: The oxidative arm and the non-oxidative arm. Both arms utilize glycolysis intermediates for the synthesis of ribose-5-phosphates while only the oxidative one generates NAPDH. The PPP is crucial to support the rapid and uncontrolled growth of cancer cells by producing both ribonucleotides for DNA/RNA building and the essential cofactor NADPH for ROS detoxification and macromolecule biosynthesis.

The oxidative PPP has been shown to be activated by oncogenic KRAS during cellular transformation and function to promote cellular proliferation, likely due to its ROS scavenger function through the generation of NADPH [73,74]. However, a recent study in a KRAS-driven mouse PDAC model indicates that the flux through oxidative PPP does not seem to be dependent on KRAS signaling [2]. It is possible that oxidative PPP in PDAC is activated due to p53 mutation since 553 has been reported to suppress the activity of oxidative PPP through direct interaction with glucose-6-phosphate dehydrogenase (G6PD), the key enzyme for oxidative PPP [75]. Contradictorily, p53 has also been shown to enhance oxidative PPP activity through the induction of TP53-inducible glycolysis and apoptosis regulator (TIGAR), which in turn inhibits glycolysis through its fructose bisphosphatase activity and promotes the flux of accumulated G6P through oxidative PPP [76]. Consistent with this notion, p53 mutant PDAC cells with low TIGAR expression seem particularly dependent on glycolysis and exhibit enhanced apoptosis following glycolysis inhibition with LDHA inhibitor [77]. Moreover, a recent study demonstrated that GOT1-mediated glutamine metabolism, instead of the oxidative PPP, plays a major role for NADPH generation and ROS homeostasis in PDAC cells [5]. While the requirement of the oxidative PPP-NADPH axis in advanced PDAC remains to be 
further evaluated, recent studies indicate that 6-phosphogluconate dehydrogenase (PGD), an enzyme of the oxidative arm of PPP, is specifically activated in metastatic PDAC [78]. PGD depletion selectively inhibits the tumorigenic activity of metastatic tumor clones [78,79]. Interestingly, the function of PGD in metastatic PDAC seems outside of the canonical oxidative PPP and involves a metabolism route similar to the pentose conversion pathway that converts glucose to PGD substrate 6-phosphogluconate (6PG) through a series of enzymes, including UDP-Glucose-6-Dehydrogenase (UGDH), Aldo-Keto Reductase 1A1 (AKR1A1), and gluconokinase (IDNK) [79] (Figure 2).

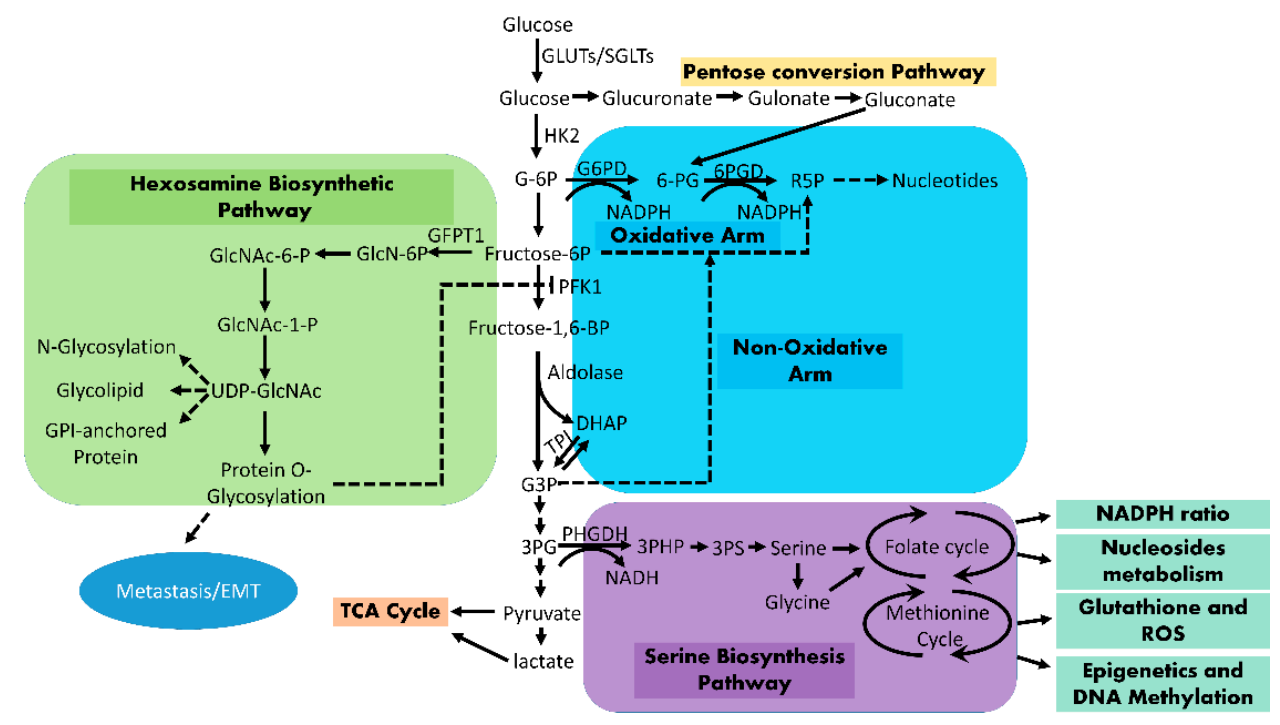

Figure 2. Enhanced glucose flux into anabolic pathways in PDAC.

In contrast to the uncertainty surrounding the role of oxidative PPP, accumulating evidence indicates that the non-oxidative arm is highly active in PDAC to promote tumor growth [80,81]. Moreover, it has been shown that oncogenic KRAS selectively activates non-oxidative PPP, likely through the induction of genes in the non-oxidative arm, such as ribulose-5-phosphate isomerase (RPIA) and ribulose-5-phosphate-3-epimerase (RPE) [2,82]. Depletion of RPIA significantly inhibited the tumorigenic activity of KRAS-driven PDAC cells, underscoring the importance of non-oxidative PPP during tumor maintenance [2,82]. Notably, elevated pyrimidine biosynthesis due to enhanced glucose flux through non-oxidative PPP has been shown to contribute to gemcitabine resistance in PDAC, and reduced expression of transketolase (TKT), a non-oxidative PPP enzyme, is correlated with increased gemcitabine sensitivity in PDAC patients [52], further supporting the translational potential of targeting non-oxidative PPP.

\subsection{Hexosamine Biosynthesis Pathway (HBP)}

HBP uses substrates, such as fructose-6-phosphate, acetyl-CoA, glutamine, and UTP, to generate UDP-GlcNAc (N-acetylglucosamine), therefore integrating multiple metabolism pathways, including glucose, amino acid, and lipid metabolism. The generated UDP-GlcNAc is used for glycosylation of proteins and lipids, or conversion to UDP-GlcNAc-derived activated monosaccharides, such as UDP-GalNAc and CMP-Neu5Ac, which are also used for glycosylation [83].

A recent study in a PDAC genetically engineered mouse (GEM) model indicated that oncogenic KRAS signaling significantly increases the flux of glycolysis intermediates through HBP by inducing the expression of glucosamine-fructose-6-phosphate aminotransferase 1 (GFPT1), the rate-liming enzyme for HBP [2]. Such induction of GFPT1 expression and enhanced glucose flux through HBP is further enhanced under hypoxia conditions to maintain cell viability [84]. GFPT1 knock down in PDAC cells strongly suppresses tumorigenic activity in vitro and in vivo, indicating the crucial role 
of HBP during the maintenance of PDAC [2]. Correspondingly, high expression of GFPT1 has been shown to be significantly correlated with poor prognosis in PDAC patients [85].

UDP-GlcNAc, the end product of HBP, is the limiting substrate for the O-linked GlcNAc modifications (O-GlcNAcylation) of proteins. Consistent with the enhanced HBP activity, protein O-GlcNAcylation is induced by KRAS oncogene as well as hypoxia in PDAC cells [2,84]. Hyper-O-GlcNAcylation in human PDAC is also associated with elevated expression of O-linked GlcNAc transferase (OGT), a key enzyme for protein O-GlcNAcylation, and reduction of O-GlcNAcase (OGA), an enzyme that removes O-GlcNAc [86]. O-GlcNAcylation has been recognized as a major type of post-translational modification, which functions to sense nutrient availability and regulate key oncoproteins, such as Nuclear Factor Kappa B (NF-KB) and Yes-associated protein 1 (YAP1), to support tumor growth [86,87]. In addition, HBP-mediated O-GlcNAcylation may also function to finetune the glucose flux in tumor cells. It was recently reported that a key glycolysis enzyme, PFK-1, is also modified with O-GlcNAcylation, which suppresses PFK-1 activity and redirects the flow of glucose metabolism toward PPP during hypoxia [88], providing a mechanism for the coordination between anabolic branches of glucose metabolism in tumor cells (Figure 2).

\subsection{Serine Biosynthesis Pathway}

As a central node for the biosynthesis of many molecules, serine biosynthesis is critical in various cancer types [89-92]. While some tumor types rely on exogenous serine, PDAC tissues are particularly low in serine [93]. On the other hand, serine biosynthesis genes are induced by oncogenic KRAS, which re-wire the PDAC metabolism to depend on de novo serine biosynthesis for survival [94]. Serine is generated de novo from 3-phosphoglycerate, a glycolysis intermediate, and is the precursor of the nonessential amino acids glycine and cysteine. Both glycine and cysteine are precursors of glutathione, which are critical for the maintenance of ROS levels in the cell. Serine metabolism is also critical for the mitochondrial redox homeostasis during hypoxia. Upon hypoxia stress, the mitochondrial enzyme SHMT2 is induced by HIF1A, and is critical for NADPH production through serine catabolism, which in turn maintains redox balance to support tumor cell survival and growth [91]. In addition, serine supplies carbon to the one-carbon pool and is involved in both DNA and histone methylation (Figure 2). Oncogenic KRAS has been shown to corporate with LKB1 loss to induce the serine-glycine-one-carbon pathway to fuel tumor growth. Accordingly, human PDAC cells with LKB1 mutations are more sensitive to the inhibition of serine biosynthesis [92].

\subsection{Mitochondrial Tricarboxylic Acid (TCA) Cycle}

The TCA cycle catalyzes the complete aerobic oxidation of glucose that occurs in the mitochondria. Mitochondria are the center of tumor metabolism reprogramming as they integrate all bioenergetics, biosynthetic, and redox signaling functions [95]. In contrast to the initial misconception that cancer cells adopt aerobic glycolysis as a result of impaired mitochondrial function, recent advances in the field indicate that a majority of tumor cells maintain the capacity to produce energy through mitochondrial oxidative phosphorylation (OXPHOS) [96]. Emerging evidences have indicated the requirement of mitochondrial metabolism in various tumor types, including pancreatic cancer [74,97-100]. The majority of glucose in tumors under in vitro culture conditions is converted into lactate, which is accordant with the pervasive belief that glucose utilization in tumor cells switches from oxidative metabolism to glycolysis. However, recent in vivo tracing experiments using isotope-labeled glucose in GEM models and cancer patients indicate that tumor tissues exhibit enhanced glucose contribution to the TCA cycle compared to normal tissue [101-105], underscoring the importance of characterizing metabolism reprogramming in physiological environments. Importantly, these in vivo flux studies in lung and pancreatic caners revealed the direct contribution to the TCA cycle from lactate, which dominates the contribution from glucose $[101,103,106]$. While a study in the PDAC GEM model indicates that glutamine contributes more to the TCA cycle than glucose does, the contribution of glucose to the 
TCA cycle is actually mostly through lactate, which allows more efficient utilization of glycolytic intermediates to support biosynthesis and tumor growth [103].

\section{Nutrient Salvage and Glucose Metabolism}

Metabolomics analysis of human PDAC indicated that multiple metabolites related to glucose and glutamine are depleted in tumors compared to adjacent normal tissues, supporting the limited nutrient availability in PDAC cells, which is likely due to the dense stroma and poor tumor perfusion [93]. Therefore, PDAC cells are engaged in multiple salvages pathways, including nutrient recycling through autophagy and nutrient scavenging from the extra-cellular space through macropinocytosis to meet nutrient requirements $[7,8]$. As a common effector for both autophagy and macropinocytosis, lysosome is concordantly activated constitutively in PDAC cells [107]. Diverse substrates, including sugars [108], glutamine [109], amino acid [10,110,111], nucleosides [112,113], and fatty acids [114,115], are generated from the nutrient salvage pathways to fuel tumor growth.

Autophagy is a lysosome-mediated self-digestion process that is critical for the maintenance of cell viability under stress conditions [116]. It is highly activated in PDAC cells and its requirement for tumor maintenance has been well-established $[7,117,118]$. As a tightly regulated process, autophagy can be induced by a variety of stress signals, including nutrient deprivation and hypoxia [119], both of which are hallmarks of human PDAC. Glucose deprivation, which is commonly observed in PDAC $[93,120]$, has been shown to activate AMPK, which in turn activates autophagy through the phosphorylation of Beclin 1, a key autophagy component [121,122]. However, it should be noted that basal autophagy in human PDAC cells is maintained at highly elevated level even under nutrient-rich conditions [7], implicating that autophagy may be constitutively activated in PDAC cells. It remains to be further evaluated whether tumor autophagy is further elevated by nutrient stress signals under in vivo conditions. On the other hand, recent studies indicate that autophagy activation leads to the induction of glycolysis $[123,124]$. However, the mechanism underlying autophagy-mediated glycolysis activation is still poorly understood.

Besides autophagic recycling, PDAC cells also scavenge nutrients by taking up the extracellular macromolecules through macropinocytosis. Oncogenic KRAS signaling is a potent inducer for macropinocytosis in PDAC cells [8,9]. In addition, a recent study indicates that macropinocytosis can also be activated by glutamine deprivation in PDAC [125]. It remains to be investigated whether additional stress signals, such as glucose deprivation or hypoxia, also induce macropinocytosis in a similar fashion. It is also not clear how macropinocytosis may affect the glucose metabolism programs in tumor cells. Recent studies largely focused on the salvage of extracellular protein or lipid as nutrient sources $[8,93,126-128]$. Given the abundance of complex carbohydrates in the extracellular space, additional efforts are warranted to investigate whether polysaccharides salvage through macropinocytosis or other uptake mechanisms may impact tumor cell glucose metabolism and oncogenic growth.

\section{Glucose Metabolism in Intra-Tumoral Crosstalk}

Human PDAC is a heterogeneous disease and recent large-scale transcriptomic analyses have classified PDAC into several molecular subtypes that show distinct clinical characteristics [129-132]. Besides the ADEX/exocrine and immunogenic subtypes, which are likely defined by signatures derived from non-neoplastic cells [130,132], the molecular signatures of cancer cells largely fall into two categories: The squamous/quasimesenchymal/basal-like subtype enriched with mesenchymal signatures and the progenitor/classical subtype enriched with epithelial signatures. Interestingly, PDAC cell lines or primary PDAC tumors of the mesenchymal subtype are associated with a more glycolytic phenotype and elevated expression level of MCT4 compared to those of the epithelial subtype [6,23], implicating distinctive metabolic dependencies among different subtypes of tumor cells. While the molecular subtypes reflect the inter-tumoral heterogeneity, recent single cell analyses of human PDAC have also identified sub-clusters of tumor cells exhibiting similar mesenchymal and 
epithelial signatures $[133,134]$, although it remains to be investigated whether these sub-clusters of tumor cells are also associated with different metabolic characteristics within the bulk tumor. It is possible that the formation of such intra-tumoral heterogeneity of tumor cells is largely dictated by the local microenvironment, such as nutrient and oxygen availability. As previously described, PDAC is characterized with large areas of hypoxic regions, likely due to poor perfusion caused by the dense stroma [44]. A recent study showed that tumor cells in hypoxic regions tend to undergo epithelial-mesenchymal transition (EMT) and exhibit elevated glycolysis compared to tumor cells in the normoxic areas [84]. Importantly, a symbiotic relationship has been identified between hypoxic tumor cells and normoxic ones. MCT4 is highly induced in hypoxic PDAC cells to mediate the excretion of lactate derived from heightened glycolysis, which is taken up through another lactate transporter, MCT1, which is exclusively expressed in the normoxic tumor cells to fuel tumor growth [84]. Similar metabolic crosstalk between MCT4 high and MCT1 high tumor cells has also been described in other cancer types [135-138], implying that such metabolic symbiosis is a common theme in the tumor ecosystem. In addition to the metabolic heterogeneity amongst tumor cells of different molecular subtypes, PDAC tumor-initiating cells (TICs) also exhibit distinctive metabolic phenotypes. It has recently been shown that, compared to proliferating tumor cells, PDAC TICs are equipped with limited metabolic plasticity and exhibit decreased glycolysis activity accompanied with enhanced mitochondrial OXPHOS $[99,100]$. As a result, PDAC TICs feature unique dependence on mitochondrial respiration that can be therapeutically targeted.

The presence of exuberant stroma is one of the most defining features of human PDAC. Extensive metabolism crosstalk occurs between tumor cells and their microenvironment, including the exchange of nutrients between PDAC cells and associated fibroblasts (CAFs) [139,140]. It has been shown that CAFs have higher metabolic flexibility than normal fibroblasts and PDAC cells also increase the autophagy in CAFs [10,141]. The non-essential amino acids (mostly alanine) released from CAFs in turn fuel the TCA cycle of tumor cells to support anabolic needs, such as lipid biosynthesis [10]. As such, CAFs promote the consumption of glucose in PDAC cells and enhance the shunt of glucose into anabolic pathways, such as serine biosynthesis [10,142]. In addition, under conditions of glucose deprivation, pancreatic cancer cells uptake collagens via micropinocytosis, which provides proline as a nutrient source to fuel the TCA cycle and macromolecular biosynthesis [143]. Metabolic interactions in the microenvironment also function to suppress anti-tumor immunity to allow malignant progression. Specifically, lactate excreted by PDAC cells has been shown to inhibit natural killer (NK) cells' function and reprogram macrophages into immunosuppressive cells [144,145]. As evidence accumulates about the metabolism interactions between the stromal and epithelial cell compartments in PDAC, it is becoming evident that co-targeting both the cancer cells and their microenvironment may contribute to improve clinical outcomes for patients.

\section{Pancreatic Cancer and Diabetes}

The initiation and progression of PDAC is also affected by systemic metabolism alterations, such as diabetes and obesity. There is a 1.5- to 2.0-fold increase in the risk of developing pancreatic cancer in type 2 diabetes mellitus patients [146,147]. The hyperglycemia, which is caused by insulin resistance and inability to suppress inappropriate hepatic glucose release, has been shown to enhance proliferation [148,149], promotes epithelial-mesenchymal transition and cancer stem cells' properties [150], and metastatic potential in pancreatic cancer [151,152]. Recently, it has been reported that high glucose concentrations in the cell culture medium induce the KRAS G12D mutation in vitro. The induction of de novo oncogenic KRAS mutations is related to the lower PFK activity in pancreatic ductal cells and elevated O-GlcNAcylation under high-glucose conditions [153]. The compromised ribonucleotide reductase (RNR) activity by O-GlcNAcylation leads to a deficiency in deoxynucleotide (dNTP) pools, genomic DNA alterations, and consequently KRAS mutations [153]. It remains to be further validated whether the elevated blood glucose level in diabetes patients could indeed induce KRAS mutations in vivo. Additionally, obesity, which is often associated with diabetes, is also an 
independent risk factor of increased pancreatic cancer. In agreement with the epidemiologic data, a high-fat diet promotes the development of pancreatic intraepithelial neoplasias (PanINs) and PDAC by the induction of inflammation and fibrosis than the control diet [154,155]. On the other hand, it has been recognized that pancreatic cancer also plays a causal role in the development of a form of new onset diabetes, namely type 3c (pancreatogenic) diabetes [156]. In contrast to classic type 3 diabetes caused by exocrine pancreatic deficiency, such as chronic pancreatitis, which is characterized with low insulin and increased peripheral insulin sensitivity, PDAC-induced type $3 \mathrm{c}$ diabetes often exhibits high insulin levels and peripheral insulin resistance, similar to type 2 diabetes [157]. It has been shown in a case-control study of patients with PDAC that hyperglycemic may precede PDAC diagnosis for a mean period of 36 to 30 months, indicating such a new onset of diabetes may serve as an early detection marker for pancreatic cancer $[158,159]$. Besides diagnosis, targeting hyperglycemic may also benefit the PDAC prevention and treatment. Metformin, a well-known antidiabetic drug that inhibits the mitochondria electron transportation chain (ETC) $[160,161]$, has been shown to be associated with increased survival among diabetic PDAC patients [162-164]. However, the beneficial effect of metformin in PDAC patients was called into question by a recent study showing a lack of correlation between metformin and PDAC patient survival [165], indicating additional in-depth studies are needed to understand the molecular mechanisms for the effect of metformin on tumor cells and systematic metabolism.

\section{Conclusions and Future Directions}

Good progress has been made in understanding reprogrammed metabolism in PDAC. The accumulated knowledge points to various unique and targetable vulnerabilities, such as in the rewired glycolytic flux and its branched pathways like PPP, HBP, serine biosynthesis, and TCA. Given the high plasticity of the metabolic pathways and complexity of metabolic crosstalk amongst tumor components, it is unlikely that we would achieve a meaningful response by targeting any single pathway. It is urgent to characterize the compensation among the metabolic pathways and also the metabolic dependence among various tumor components, which may help to identify new metabolism drug targets. Recent concerted efforts on the genomic and epigenomic profiling of tumors from both human and GEM models, in particular the recent advances in the field of single cell sequencing, have revealed the complexity of PDAC with unprecedented resolution. Such knowledge will enhance our understanding of metabolic crosstalk in the TME and may help identify effective strategies targeting metabolism in PDAC.

Funding: This work was funded by Career Development Award (H.Y.) and Pathway to Leadership Award (W.Y.) from Pancreatic Cancer Action Network-AACR and NCI grant R01CA214793 (H.Y.).

Conflicts of Interest: The authors declare no conflict of interest.

\section{References}

1. Siegel, R.L.; Miller, K.D.; Jemal, A. Cancer statistics, 2019. CA Cancer J. Clin. 2019, 69, 7-34. [CrossRef] [PubMed]

2. Ying, H.; Kimmelman, A.C.; Lyssiotis, C.A.; Hua, S.; Chu, G.C.; Fletcher-Sananikone, E.; Locasale, J.W.; Son, J.; Zhang, H.; Coloff, J.L.; et al. Oncogenic Kras maintains pancreatic tumors through regulation of anabolic glucose metabolism. Cell 2012, 149, 656-670. [CrossRef] [PubMed]

3. Hanahan, D.; Weinberg, R.A. Hallmarks of cancer: The next generation. Cell 2011, 144, 646-674. [CrossRef] [PubMed]

4. Tanner, L.B.; Goglia, A.G.; Wei, M.H.; Sehgal, T.; Parsons, L.R.; Park, J.O.; White, E.; Toettcher, J.E.; Rabinowitz, J.D. Four Key Steps Control Glycolytic Flux in Mammalian Cells. Cell Syst. 2018, 7, 49-62. [CrossRef] [PubMed]

5. Son, J.; Lyssiotis, C.A.; Ying, H.; Wang, X.; Hua, S.; Ligorio, M.; Perera, R.M.; Ferrone, C.R.; Mullarky, E.; Shyh-Chang, N.; et al. Glutamine supports pancreatic cancer growth through a KRAS-regulated metabolic pathway. Nature 2013, 496, 101-105. [CrossRef] [PubMed] 
6. Daemen, A.; Peterson, D.; Sahu, N.; McCord, R.; Du, X.; Liu, B.; Kowanetz, K.; Hong, R.; Moffat, J.; Gao, M.; et al. Metabolite profiling stratifies pancreatic ductal adenocarcinomas into subtypes with distinct sensitivities to metabolic inhibitors. Proc. Natl. Acad. Sci. USA 2015, 112, E4410-E4417. [CrossRef] [PubMed]

7. Yang, S.; Wang, X.; Contino, G.; Liesa, M.; Sahin, E.; Ying, H.; Bause, A.; Li, Y.; Stommel, J.M.; Dell'antonio, G.; et al. Pancreatic cancers require autophagy for tumor growth. Genes Dev. 2011, 25, 717-729. [CrossRef]

8. Commisso, C.; Davidson, S.M.; Soydaner-Azeloglu, R.G.; Parker, S.J.; Kamphorst, J.J.; Hackett, S.; Grabocka, E.; Nofal, M.; Drebin, J.A.; Thompson, C.B.; et al. Macropinocytosis of protein is an amino acid supply route in Ras-transformed cells. Nature 2013, 497, 633-637. [CrossRef]

9. Yao, W.; Rose, J.L.; Wang, W.; Seth, S.; Jiang, H.; Taguchi, A.; Liu, J.; Yan, L.; Kapoor, A.; Hou, P.; et al. Syndecan 1 is a critical mediator of macropinocytosis in pancreatic cancer. Nature 2019, 568, 410-414. [CrossRef]

10. Sousa, C.M.; Biancur, D.E.; Wang, X.; Halbrook, C.J.; Sherman, M.H.; Zhang, L.; Kremer, D.; Hwang, R.F.; Witkiewicz, A.K.; Ying, H.; et al. Pancreatic stellate cells support tumour metabolism through autophagic alanine secretion. Nature 2016, 536, 479-483. [CrossRef]

11. Halbrook, C.J.; Pontious, C.; Kovalenko, I.; Lapienyte, L.; Dreyer, S.; Lee, H.J.; Thurston, G.; Zhang, Y.; Lazarus, J.; Sajjakulnukit, P.; et al. Macrophage-Released Pyrimidines Inhibit Gemcitabine Therapy in Pancreatic Cancer. Cell Metab. 2019, 29, 1390-1399. [CrossRef] [PubMed]

12. Luengo, A.; Gui, D.Y.; Vander Heiden, M.G. Targeting Metabolism for Cancer Therapy. Cell Chem. Biol. 2017, 24, 1161-1180. [CrossRef] [PubMed]

13. Basturk, O.; Singh, R.; Kaygusuz, E.; Balci, S.; Dursun, N.; Culhaci, N.; Adsay, N.V. GLUT-1 expression in pancreatic neoplasia: Implications in pathogenesis, diagnosis, and prognosis. Pancreas 2011, 40, 187-192. [CrossRef] [PubMed]

14. Reske, S.N.; Grillenberger, K.G.; Glatting, G.; Port, M.; Hildebrandt, M.; Gansauge, F.; Beger, H.G. Overexpression of glucose transporter 1 and increased FDG uptake in pancreatic carcinoma. J. Nucl. Med. 1997, 38, 1344-1348. [PubMed]

15. Higashi, T.; Tamaki, N.; Honda, T.; Torizuka, T.; Kimura, T.; Inokuma, T.; Ohshio, G.; Hosotani, R.; Imamura, M.; Konishi, J. Expression of glucose transporters in human pancreatic tumors compared with increased FDG accumulation in PET study. J. Nucl. Med. 1997, 38, 1337-1344. [PubMed]

16. Kurahara, H.; Maemura, K.; Mataki, Y.; Sakoda, M.; Iino, S.; Kawasaki, Y.; Arigami, T.; Mori, S.; Kijima, Y.; Ueno, S.; et al. Significance of Glucose Transporter Type 1 (GLUT-1) Expression in the Therapeutic Strategy for Pancreatic Ductal Adenocarcinoma. Ann. Surg. Oncol. 2018, 25, 1432-1439. [CrossRef] [PubMed]

17. Nagarajan, A.; Dogra, S.K.; Sun, L.; Gandotra, N.; Ho, T.; Cai, G.; Cline, G.; Kumar, P.; Cowles, R.A.; Wajapeyee, N. Paraoxonase 2 Facilitates Pancreatic Cancer Growth and Metastasis by Stimulating GLUT1-Mediated Glucose Transport. Mol. Cell 2017, 67, 685-701. [CrossRef] [PubMed]

18. Chao, E.C.; Henry, R.R. SGLT2 inhibition-A novel strategy for diabetes treatment. Nat. Rev. Drug Discov. 2010, 9, 551-559. [CrossRef]

19. Scafoglio, C.; Hirayama, B.A.; Kepe, V.; Liu, J.; Ghezzi, C.; Satyamurthy, N.; Moatamed, N.A.; Huang, J.; Koepsell, H.; Barrio, J.R.; et al. Functional expression of sodium-glucose transporters in cancer. Proc. Natl. Acad. Sci. USA 2015, 112, E4111-E4119. [CrossRef]

20. Hopkins, B.D.; Pauli, C.; Du, X.; Wang, D.G.; Li, X.; Wu, D.; Amadiume, S.C.; Goncalves, M.D.; Hodakoski, C.; Lundquist, M.R.; et al. Suppression of insulin feedback enhances the efficacy of PI3K inhibitors. Nature 2018, 560, 499-503. [CrossRef]

21. Ui, M. A role of phosphofructokinase in $\mathrm{pH}-\mathrm{dependent} \mathrm{regulation} \mathrm{of} \mathrm{glycolysis.} \mathrm{Biochim.} \mathrm{Biophys.} \mathrm{Acta} \mathrm{1966,}$ 124, 310-322. [CrossRef]

22. Kong, S.C.; Nohr-Nielsen, A.; Zeeberg, K.; Reshkin, S.J.; Hoffmann, E.K.; Novak, I.; Pedersen, S.F. Monocarboxylate Transporters MCT1 and MCT4 Regulate Migration and Invasion of Pancreatic Ductal Adenocarcinoma Cells. Pancreas 2016, 45, 1036-1047. [CrossRef] [PubMed]

23. Baek, G.; Tse, Y.F.; Hu, Z.; Cox, D.; Buboltz, N.; McCue, P.; Yeo, C.J.; White, M.A.; DeBerardinis, R.J.; Knudsen, E.S.; et al. MCT4 defines a glycolytic subtype of pancreatic cancer with poor prognosis and unique metabolic dependencies. Cell Rep. 2014, 9, 2233-2249. [CrossRef] [PubMed]

24. Kirk, P.; Wilson, M.C.; Heddle, C.; Brown, M.H.; Barclay, A.N.; Halestrap, A.P. CD147 is tightly associated with lactate transporters MCT1 and MCT4 and facilitates their cell surface expression. EMBO J. 2000, 19, 3896-3904. [CrossRef] [PubMed] 
25. Riethdorf, S.; Reimers, N.; Assmann, V.; Kornfeld, J.W.; Terracciano, L.; Sauter, G.; Pantel, K. High incidence of EMMPRIN expression in human tumors. Int. J. Cancer 2006, 119, 1800-1810. [CrossRef] [PubMed]

26. Schneiderhan, W.; Scheler, M.; Holzmann, K.H.; Marx, M.; Gschwend, J.E.; Bucholz, M.; Gress, T.M.; Seufferlein, T.; Adler, G.; Oswald, F. CD147 silencing inhibits lactate transport and reduces malignant potential of pancreatic cancer cells in in vivo and in vitro models. Gut 2009, 58, 1391-1398. [CrossRef] [PubMed]

27. Dovmark, T.H.; Saccomano, M.; Hulikova, A.; Alves, F.; Swietach, P. Connexin-43 channels are a pathway for discharging lactate from glycolytic pancreatic ductal adenocarcinoma cells. Oncogene 2017, 36, 4538-4550. [CrossRef] [PubMed]

28. Garland, P.B.; Randle, P.J.; Newsholme, E.A. Citrate as an Intermediary in the Inhibition of Phosphofructokinase in Rat Heart Muscle by Fatty Acids, Ketone Bodies, Pyruvate, Diabetes, and Starvation. Nature 1963, 200, 169-170. [CrossRef]

29. Carrer, A.; Trefely, S.; Zhao, S.; Campbell, S.L.; Norgard, R.J.; Schultz, K.C.; Sidoli, S.; Parris, J.L.D.; Affronti, H.C.; Sivanand, S.; et al. Acetyl-CoA Metabolism Supports Multistep Pancreatic Tumorigenesis. Cancer Discov. 2019, 9, 416-435. [CrossRef]

30. Fernandez, S.; Viola, J.M.; Torres, A.; Wallace, M.; Trefely, S.; Zhao, S.; Affronti, H.C.; Gengatharan, J.M.; Guertin, D.A.; Snyder, N.W.; et al. Adipocyte ACLY Facilitates Dietary Carbohydrate Handling to Maintain Metabolic Homeostasis in Females. Cell Rep. 2019, 27, 2772-2784. [CrossRef]

31. Sakakibara, R.; Kato, M.; Okamura, N.; Nakagawa, T.; Komada, Y.; Tominaga, N.; Shimojo, M.; Fukasawa, M. Characterization of a human placental fructose-6-phosphate, 2-kinase/fructose-2,6-bisphosphatase. J. Biochem. 1997, 122, 122-128. [CrossRef] [PubMed]

32. Chesney, J.; Mitchell, R.; Benigni, F.; Bacher, M.; Spiegel, L.; Al-Abed, Y.; Han, J.H.; Metz, C.; Bucala, R. An inducible gene product for 6-phosphofructo-2-kinase with an AU-rich instability element: Role in tumor cell glycolysis and the Warburg effect. Proc. Natl. Acad. Sci. USA 1999, 96, 3047-3052. [CrossRef] [PubMed]

33. Minchenko, A.; Leshchinsky, I.; Opentanova, I.; Sang, N.; Srinivas, V.; Armstead, V.; Caro, J. Hypoxia-inducible factor-1-mediated expression of the 6-phosphofructo-2-kinase/fructose-2, 6-bisphosphatase-3 (PFKFB3) gene. Its possible role in the Warburg effect. J. Biol. Chem. 2002, 277, 6183-6187. [CrossRef] [PubMed]

34. Atsumi, T.; Chesney, J.; Metz, C.; Leng, L.; Donnelly, S.; Makita, Z.; Mitchell, R.; Bucala, R. High Expression of Inducible 6-Phosphofructo-2-Kinase/Fructose-2,6-Bisphosphatase (iPFK-2; PFKFB3) in Human Cancers. Cancer Res. 2002, 62, 5881-5887.

35. Kotiah, S.D.; Caro, J. Elevation of PFKFB3 and TIGAR levels in pancreatic cancer. J. Clin. Oncol. 2010, 28, e14679. [CrossRef]

36. Telang, S.; Yalcin, A.; Clem, A.L.; Bucala, R.; Lane, A.N.; Eaton, J.W.; Chesney, J. Ras transformation requires metabolic control by 6-phosphofructo-2-kinase. Oncogene 2006, 25, 7225-7234. [CrossRef]

37. Gonzalez, P.S.; O’Prey, J.; Cardaci, S.; Barthet, V.J.A.; Sakamaki, J.I.; Beaumatin, F.; Roseweir, A.; Gay, D.M.; Mackay, G.; Malviya, G.; et al. Mannose impairs tumour growth and enhances chemotherapy. Nature 2018, 563, 719-723. [CrossRef]

38. DeRossi, C.; Bode, L.; Eklund, E.A.; Zhang, F.; Davis, J.A.; Westphal, V.; Wang, L.; Borowsky, A.D.; Freeze, H.H. Ablation of mouse phosphomannose isomerase (Mpi) causes mannose 6-phosphate accumulation, toxicity, and embryonic lethality. J. Biol. Chem. 2006, 281, 5916-5927. [CrossRef]

39. Racker, E.; Resnick, R.J.; Feldman, R. Glycolysis and methylaminoisobutyrate uptake in rat-1 cells transfected with ras or myc oncogenes. Proc. Natl. Acad. Sci. USA 1985, 82, 3535-3538. [CrossRef]

40. Yun, J.; Rago, C.; Cheong, I.; Pagliarini, R.; Angenendt, P.; Rajagopalan, H.; Schmidt, K.; Willson, J.K.; Markowitz, S.; Zhou, S.; et al. Glucose deprivation contributes to the development of KRAS pathway mutations in tumor cells. Science 2009, 325, 1555-1559. [CrossRef]

41. Blake, D.R.; Vaseva, A.V.; Hodge, R.G.; Kline, M.P.; Gilbert, T.S.K.; Tyagi, V.; Huang, D.; Whiten, G.C.; Larson, J.E.; Wang, X.; et al. Application of a MYC degradation screen identifies sensitivity to CDK9 inhibitors in KRAS-mutant pancreatic cancer. Sci. Signal. 2019, 12, eaav7259. [CrossRef] [PubMed]

42. Soucek, L.; Whitfield, J.; Martins, C.P.; Finch, A.J.; Murphy, D.J.; Sodir, N.M.; Karnezis, A.N.; Swigart, L.B.; Nasi, S.; Evan, G.I. Modelling Myc inhibition as a cancer therapy. Nature 2008, 455, 679-683. [CrossRef] [PubMed] 
43. Soucek, L.; Whitfield, J.R.; Sodir, N.M.; Masso-Valles, D.; Serrano, E.; Karnezis, A.N.; Swigart, L.B.; Evan, G.I. Inhibition of Myc family proteins eradicates KRas-driven lung cancer in mice. Genes Dev. 2013, 27, 504-513. [CrossRef] [PubMed]

44. Koong, A.C.; Mehta, V.K.; Le, Q.T.; Fisher, G.A.; Terris, D.J.; Brown, J.M.; Bastidas, A.J.; Vierra, M. Pancreatic tumors show high levels of hypoxia. Int. J. Radiat. Oncol. Biol. Phys. 2000, 48, 919-922. [CrossRef]

45. Ivan, M.; Kondo, K.; Yang, H.; Kim, W.; Valiando, J.; Ohh, M.; Salic, A.; Asara, J.M.; Lane, W.S.; Kaelin, W.G., Jr. HIFalpha targeted for VHL-mediated destruction by proline hydroxylation: Implications for O2 sensing. Science 2001, 292, 464-468. [CrossRef] [PubMed]

46. Iyer, N.V.; Kotch, L.E.; Agani, F.; Leung, S.W.; Laughner, E.; Wenger, R.H.; Gassmann, M.; Gearhart, J.D.; Lawler, A.M.; Yu, A.Y.; et al. Cellular and developmental control of $\mathrm{O} 2$ homeostasis by hypoxia-inducible factor 1 alpha. Genes Dev. 1998, 12, 149-162. [CrossRef]

47. Zhong, H.; De Marzo, A.M.; Laughner, E.; Lim, M.; Hilton, D.A.; Zagzag, D.; Buechler, P.; Isaacs, W.B.; Semenza, G.L.; Simons, J.W. Overexpression of hypoxia-inducible factor 1alpha in common human cancers and their metastases. Cancer Res. 1999, 59, 5830-5835.

48. Chen, C.; Pore, N.; Behrooz, A.; Ismail-Beigi, F.; Maity, A. Regulation of glut1 mRNA by hypoxia-inducible factor-1. Interaction between H-ras and hypoxia. J. Biol. Chem. 2001, 276, 9519-9525. [CrossRef]

49. Blancher, C.; Moore, J.W.; Robertson, N.; Harris, A.L. Effects of ras and von Hippel-Lindau (VHL) gene mutations on hypoxia-inducible factor (HIF)-1alpha, HIF-2alpha, and vascular endothelial growth factor expression and their regulation by the phosphatidylinositol 3'-kinase/Akt signaling pathway. Cancer Res. 2001, 61, 7349-7355.

50. Chauhan, S.C.; Ebeling, M.C.; Maher, D.M.; Koch, M.D.; Watanabe, A.; Aburatani, H.; Lio, Y.; Jaggi, M. MUC13 mucin augments pancreatic tumorigenesis. Mol. Cancer Ther. 2012, 11, 24-33. [CrossRef]

51. Kumari, S.; Khan, S.; Gupta, S.C.; Kashyap, V.K.; Yallapu, M.M.; Chauhan, S.C.; Jaggi, M. MUC13 contributes to rewiring of glucose metabolism in pancreatic cancer. Oncogenesis 2018, 7, 19. [CrossRef] [PubMed]

52. Shukla, S.K.; Purohit, V.; Mehla, K.; Gunda, V.; Chaika, N.V.; Vernucci, E.; King, R.J.; Abrego, J.; Goode, G.D.; Dasgupta, A.; et al. MUC1 and HIF-1alpha Signaling Crosstalk Induces Anabolic Glucose Metabolism to Impart Gemcitabine Resistance to Pancreatic Cancer. Cancer Cell 2017, 32, 392. [CrossRef] [PubMed]

53. Cui, J.; Shi, M.; Xie, D.; Wei, D.; Jia, Z.; Zheng, S.; Gao, Y.; Huang, S.; Xie, K. FOXM1 promotes the warburg effect and pancreatic cancer progression via transactivation of LDHA expression. Clin. Cancer Res. 2014, 20, 2595-2606. [CrossRef] [PubMed]

54. Shi, M.; Cui, J.; Du, J.; Wei, D.; Jia, Z.; Zhang, J.; Zhu, Z.; Gao, Y.; Xie, K. A novel KLF4/LDHA signaling pathway regulates aerobic glycolysis in and progression of pancreatic cancer. Clin. Cancer Res. 2014, 20, 4370-4380. [CrossRef] [PubMed]

55. An, M.X.; Li, S.; Yao, H.B.; Li, C.; Wang, J.M.; Sun, J.; Li, X.Y.; Meng, X.N.; Wang, H.Q. BAG3 directly stabilizes Hexokinase 2 mRNA and promotes aerobic glycolysis in pancreatic cancer cells. J. Cell Biol. 2017, 216, 4091-4105. [CrossRef] [PubMed]

56. Liao, Q.; Ozawa, F.; Friess, H.; Zimmermann, A.; Takayama, S.; Reed, J.C.; Kleeff, J.; Buchler, M.W. The anti-apoptotic protein BAG-3 is overexpressed in pancreatic cancer and induced by heat stress in pancreatic cancer cell lines. FEBS Lett. 2001, 503, 151-157. [CrossRef]

57. Jiang, S.; Zhang, L.F.; Zhang, H.W.; Hu, S.; Lu, M.H.; Liang, S.; Li, B.; Li, Y.; Li, D.; Wang, E.D.; et al. A novel miR-155/miR-143 cascade controls glycolysis by regulating hexokinase 2 in breast cancer cells. EMBO J. 2012, 31, 1985-1998. [CrossRef]

58. Fang, R.; Xiao, T.; Fang, Z.; Sun, Y.; Li, F.; Gao, Y.; Feng, Y.; Li, L.; Wang, Y.; Liu, X.; et al. MicroRNA-143 (miR-143) regulates cancer glycolysis via targeting hexokinase 2 gene. J. Biol. Chem. 2012, 287, 23227-23235. [CrossRef]

59. Kent, O.A.; Chivukula, R.R.; Mullendore, M.; Wentzel, E.A.; Feldmann, G.; Lee, K.H.; Liu, S.; Leach, S.D.; Maitra, A.; Mendell, J.T. Repression of the miR-143/145 cluster by oncogenic Ras initiates a tumor-promoting feed-forward pathway. Genes Dev. 2010, 24, 2754-2759. [CrossRef]

60. Chang, T.C.; Wentzel, E.A.; Kent, O.A.; Ramachandran, K.; Mullendore, M.; Lee, K.H.; Feldmann, G.; Yamakuchi, M.; Ferlito, M.; Lowenstein, C.J.; et al. Transactivation of miR-34a by p53 broadly influences gene expression and promotes apoptosis. Mol. Cell 2007, 26, 745-752. [CrossRef] 
61. Jamieson, N.B.; Morran, D.C.; Morton, J.P.; Ali, A.; Dickson, E.J.; Carter, C.R.; Sansom, O.J.; Evans, T.R.; McKay, C.J.; Oien, K.A. MicroRNA molecular profiles associated with diagnosis, clinicopathologic criteria, and overall survival in patients with resectable pancreatic ductal adenocarcinoma. Clin. Cancer Res. 2012, 18, 534-545. [CrossRef]

62. Xiao, X.; Huang, X.; Ye, F.; Chen, B.; Song, C.; Wen, J.; Zhang, Z.; Zheng, G.; Tang, H.; Xie, X. The miR-34a-LDHA axis regulates glucose metabolism and tumor growth in breast cancer. Sci. Rep. 2016, 6, 21735. [CrossRef] [PubMed]

63. Kim, H.R.; Roe, J.S.; Lee, J.E.; Cho, E.J.; Youn, H.D. p53 regulates glucose metabolism by miR-34a. Biochem. Biophys. Res. Commun. 2013, 437, 225-231. [CrossRef] [PubMed]

64. Marsin, A.S.; Bouzin, C.; Bertrand, L.; Hue, L. The stimulation of glycolysis by hypoxia in activated monocytes is mediated by AMP-activated protein kinase and inducible 6-phosphofructo-2-kinase. J. Biol. Chem. 2002, 277, 30778-30783. [CrossRef] [PubMed]

65. Kato, K.; Ogura, T.; Kishimoto, A.; Minegishi, Y.; Nakajima, N.; Miyazaki, M.; Esumi, H. Critical roles of AMP-activated protein kinase in constitutive tolerance of cancer cells to nutrient deprivation and tumor formation. Oncogene 2002, 21, 6082-6090. [CrossRef]

66. Zhao, D.; Zou, S.W.; Liu, Y.; Zhou, X.; Mo, Y.; Wang, P.; Xu, Y.H.; Dong, B.; Xiong, Y.; Lei, Q.Y.; et al. Lysine-5 acetylation negatively regulates lactate dehydrogenase $\mathrm{A}$ and is decreased in pancreatic cancer. Cancer Cell 2013, 23, 464-476. [CrossRef]

67. Ji, S.; Qin, Y.; Liang, C.; Huang, R.; Shi, S.; Liu, J.; Jin, K.; Liang, D.; Xu, W.; Zhang, B.; et al. FBW7 (F-box and WD Repeat Domain-Containing 7) Negatively Regulates Glucose Metabolism by Targeting the c-Myc/TXNIP (Thioredoxin-Binding Protein) Axis in Pancreatic Cancer. Clin. Cancer Res. Off. J. Am. Assoc. Cancer Res. 2016, 22, 3950-3960. [CrossRef] [PubMed]

68. Ji, S.; Qin, Y.; Shi, S.; Liu, X.; Hu, H.; Zhou, H.; Gao, J.; Zhang, B.; Xu, W.; Liu, J.; et al. ERK kinase phosphorylates and destabilizes the tumor suppressor FBW7 in pancreatic cancer. Cell Res. 2015, 25, 561-573. [CrossRef] [PubMed]

69. Hu, H.; Juvekar, A.; Lyssiotis, C.A.; Lien, E.C.; Albeck, J.G.; Oh, D.; Varma, G.; Hung, Y.P.; Ullas, S.; Lauring, J.; et al. Phosphoinositide 3-Kinase Regulates Glycolysis through Mobilization of Aldolase from the Actin Cytoskeleton. Cell 2016, 164, 433-446. [CrossRef]

70. Rodriguez-Viciana, P.; Warne, P.H.; Khwaja, A.; Marte, B.M.; Pappin, D.; Das, P.; Waterfield, M.D.; Ridley, A.; Downward, J. Role of phosphoinositide 3-OH kinase in cell transformation and control of the actin cytoskeleton by Ras. Cell 1997, 89, 457-467. [CrossRef]

71. Wu, C.Y.; Carpenter, E.S.; Takeuchi, K.K.; Halbrook, C.J.; Peverley, L.V.; Bien, H.; Hall, J.C.; DelGiorno, K.E.; Pal, D.; Song, Y.; et al. PI3K regulation of RAC1 is required for KRAS-induced pancreatic tumorigenesis in mice. Gastroenterology 2014, 147, 1405-1416. [CrossRef] [PubMed]

72. Dong, X.; Tang, H.; Hess, K.R.; Abbruzzese, J.L.; Li, D. Glucose metabolism gene polymorphisms and clinical outcome in pancreatic cancer. Cancer 2011, 117, 480-491. [CrossRef]

73. Recktenwald, C.V.; Kellner, R.; Lichtenfels, R.; Seliger, B. Altered detoxification status and increased resistance to oxidative stress by K-ras transformation. Cancer Res. 2008, 68, 10086-10093. [CrossRef]

74. Weinberg, F.; Hamanaka, R.; Wheaton, W.W.; Weinberg, S.; Joseph, J.; Lopez, M.; Kalyanaraman, B.; Mutlu, G.M.; Budinger, G.R.; Chandel, N.S. Mitochondrial metabolism and ROS generation are essential for Kras-mediated tumorigenicity. Proc. Natl. Acad. Sci. USA 2010, 107, 8788-8793. [CrossRef] [PubMed]

75. Jiang, P.; Du, W.; Wang, X.; Mancuso, A.; Gao, X.; Wu, M.; Yang, X. p53 regulates biosynthesis through direct inactivation of glucose-6-phosphate dehydrogenase. Nat. Cell Biol. 2011, 13, 310-316. [CrossRef] [PubMed]

76. Bensaad, K.; Tsuruta, A.; Selak, M.A.; Vidal, M.N.; Nakano, K.; Bartrons, R.; Gottlieb, E.; Vousden, K.H. TIGAR, a p53-inducible regulator of glycolysis and apoptosis. Cell 2006, 126, 107-120. [CrossRef] [PubMed]

77. Rajeshkumar, N.V.; Dutta, P.; Yabuuchi, S.; de Wilde, R.F.; Martinez, G.V.; Le, A.; Kamphorst, J.J.; Rabinowitz, J.D.; Jain, S.K.; Hidalgo, M.; et al. Therapeutic Targeting of the Warburg Effect in Pancreatic Cancer Relies on an Absence of p53 Function. Cancer Res. 2015, 75, 3355-3364. [CrossRef] [PubMed]

78. McDonald, O.G.; Li, X.; Saunders, T.; Tryggvadottir, R.; Mentch, S.J.; Warmoes, M.O.; Word, A.E.; Carrer, A.; Salz, T.H.; Natsume, S.; et al. Epigenomic reprogramming during pancreatic cancer progression links anabolic glucose metabolism to distant metastasis. Nat. Genet. 2017, 49, 367-376. [CrossRef]

79. Bechard, M.E.; Word, A.E.; Tran, A.V.; Liu, X.; Locasale, J.W.; McDonald, O.G. Pentose conversions support the tumorigenesis of pancreatic cancer distant metastases. Oncogene 2018, 37, 5248-5256. [CrossRef] 
80. Boros, L.G.; Lerner, M.R.; Morgan, D.L.; Taylor, S.L.; Smith, B.J.; Postier, R.G.; Brackett, D.J. [1,2-13C2]-D-glucose profiles of the serum, liver, pancreas, and DMBA-induced pancreatic tumors of rats. Pancreas 2005, 31, 337-343. [CrossRef]

81. Liu, H.; Huang, D.; McArthur, D.L.; Boros, L.G.; Nissen, N.; Heaney, A.P. Fructose induces transketolase flux to promote pancreatic cancer growth. Cancer Res. 2010, 70, 6368-6376. [CrossRef] [PubMed]

82. Santana-Codina, N.; Roeth, A.A.; Zhang, Y.; Yang, A.; Mashadova, O.; Asara, J.M.; Wang, X.; Bronson, R.T.; Lyssiotis, C.A.; Ying, H.; et al. Oncogenic KRAS supports pancreatic cancer through regulation of nucleotide synthesis. Nat. Commun. 2018, 9, 4945. [CrossRef] [PubMed]

83. Vasconcelos-Dos-Santos, A.; Oliveira, I.A.; Lucena, M.C.; Mantuano, N.R.; Whelan, S.A.; Dias, W.B.; Todeschini, A.R. Biosynthetic Machinery Involved in Aberrant Glycosylation: Promising Targets for Developing of Drugs Against Cancer. Front. Oncol. 2015, 5, 138. [CrossRef]

84. Guillaumond, F.; Leca, J.; Olivares, O.; Lavaut, M.N.; Vidal, N.; Berthezene, P.; Dusetti, N.J.; Loncle, C.; Calvo, E.; Turrini, O.; et al. Strengthened glycolysis under hypoxia supports tumor symbiosis and hexosamine biosynthesis in pancreatic adenocarcinoma. Proc. Natl. Acad. Sci. USA 2013, 110, 3919-3924. [CrossRef] [PubMed]

85. Yang, C.; Peng, P.; Li, L.; Shao, M.; Zhao, J.; Wang, L.; Duan, F.; Song, S.; Wu, H.; Zhang, J.; et al. High expression of GFAT1 predicts poor prognosis in patients with pancreatic cancer. Sci. Rep. 2016, 6, 39044. [CrossRef]

86. Ma, Z.; Vocadlo, D.J.; Vosseller, K. Hyper-O-GlcNAcylation is anti-apoptotic and maintains constitutive NF-kappaB activity in pancreatic cancer cells. J. Biol. Chem. 2013, 288, 15121-15130. [CrossRef]

87. Peng, C.; Zhu, Y.; Zhang, W.; Liao, Q.; Chen, Y.; Zhao, X.; Guo, Q.; Shen, P.; Zhen, B.; Qian, X.; et al. Regulation of the Hippo-YAP Pathway by Glucose Sensor O-GlcNAcylation. Mol. Cell 2017, 68, 591-604. [CrossRef]

88. Yi, W.; Clark, P.M.; Mason, D.E.; Keenan, M.C.; Hill, C.; Goddard, W.A., III.; Peters, E.C.; Driggers, E.M.; Hsieh-Wilson, L.C. Phosphofructokinase 1 glycosylation regulates cell growth and metabolism. Science 2012, 337, 975-980. [CrossRef]

89. Maddocks, O.D.; Labuschagne, C.F.; Adams, P.D.; Vousden, K.H. Serine Metabolism Supports the Methionine Cycle and DNA/RNA Methylation through De Novo ATP Synthesis in Cancer Cells. Mol. Cell 2016, 61, 210-221. [CrossRef]

90. Possemato, R.; Marks, K.M.; Shaul, Y.D.; Pacold, M.E.; Kim, D.; Birsoy, K.; Sethumadhavan, S.; Woo, H.K.; Jang, H.G.; Jha, A.K.; et al. Functional genomics reveal that the serine synthesis pathway is essential in breast cancer. Nature 2011, 476, 346-350. [CrossRef]

91. Ye, J.; Fan, J.; Venneti, S.; Wan, Y.W.; Pawel, B.R.; Zhang, J.; Finley, L.W.; Lu, C.; Lindsten, T.; Cross, J.R.; et al. Serine catabolism regulates mitochondrial redox control during hypoxia. Cancer Discov. 2014, 4, 1406-1417. [CrossRef] [PubMed]

92. Kottakis, F.; Nicolay, B.N.; Roumane, A.; Karnik, R.; Gu, H.; Nagle, J.M.; Boukhali, M.; Hayward, M.C.; Li, Y.Y.; Chen, T.; et al. LKB1 loss links serine metabolism to DNA methylation and tumorigenesis. Nature 2016, 539, 390-395. [CrossRef] [PubMed]

93. Kamphorst, J.J.; Nofal, M.; Commisso, C.; Hackett, S.R.; Lu, W.; Grabocka, E.; Vander Heiden, M.G.; Miller, G.; Drebin, J.A.; Bar-Sagi, D.; et al. Human pancreatic cancer tumors are nutrient poor and tumor cells actively scavenge extracellular protein. Cancer Res. 2015, 75, 544-553. [CrossRef] [PubMed]

94. Maddocks, O.D.K.; Athineos, D.; Cheung, E.C.; Lee, P.; Zhang, T.; van den Broek, N.J.F.; Mackay, G.M.; Labuschagne, C.F.; Gay, D.; Kruiswijk, F.; et al. Modulating the therapeutic response of tumours to dietary serine and glycine starvation. Nature 2017, 544, 372-376. [CrossRef] [PubMed]

95. Vyas, S.; Zaganjor, E.; Haigis, M.C. Mitochondria and Cancer. Cell 2016, 166, 555-566. [CrossRef] [PubMed]

96. DeBerardinis, R.J.; Chandel, N.S. Fundamentals of cancer metabolism. Sci. Adv. 2016, 2, e1600200. [CrossRef]

97. Joshi, S.; Tolkunov, D.; Aviv, H.; Hakimi, A.A.; Yao, M.; Hsieh, J.J.; Ganesan, S.; Chan, C.S.; White, E. The Genomic Landscape of Renal Oncocytoma Identifies a Metabolic Barrier to Tumorigenesis. Cell Rep. 2015, 13, 1895-1908. [CrossRef] [PubMed]

98. Martinez-Reyes, I.; Diebold, L.P.; Kong, H.; Schieber, M.; Huang, H.; Hensley, C.T.; Mehta, M.M.; Wang, T.; Santos, J.H.; Woychik, R.; et al. TCA Cycle and Mitochondrial Membrane Potential Are Necessary for Diverse Biological Functions. Mol. Cell 2016, 61, 199-209. [CrossRef] 
99. Sancho, P.; Burgos-Ramos, E.; Tavera, A.; Bou Kheir, T.; Jagust, P.; Schoenhals, M.; Barneda, D.; Sellers, K.; Campos-Olivas, R.; Grana, O.; et al. MYC/PGC-1alpha Balance Determines the Metabolic Phenotype and Plasticity of Pancreatic Cancer Stem Cells. Cell Metab. 2015, 22, 590-605. [CrossRef]

100. Viale, A.; Pettazzoni, P.; Lyssiotis, C.A.; Ying, H.; Sanchez, N.; Marchesini, M.; Carugo, A.; Green, T.; Seth, S.; Giuliani, V.; et al. Oncogene ablation-resistant pancreatic cancer cells depend on mitochondrial function. Nature 2014, 514, 628-632. [CrossRef]

101. Hensley, C.T.; Faubert, B.; Yuan, Q.; Lev-Cohain, N.; Jin, E.; Kim, J.; Jiang, L.; Ko, B.; Skelton, R.; Loudat, L.; et al. Metabolic Heterogeneity in Human Lung Tumors. Cell 2016, 164, 681-694. [CrossRef] [PubMed]

102. Davidson, S.M.; Papagiannakopoulos, T.; Olenchock, B.A.; Heyman, J.E.; Keibler, M.A.; Luengo, A.; Bauer, M.R.; Jha, A.K.; O’Brien, J.P.; Pierce, K.A.; et al. Environment Impacts the Metabolic Dependencies of Ras-Driven Non-Small Cell Lung Cancer. Cell Metab. 2016, 23, 517-528. [CrossRef] [PubMed]

103. Hui, S.; Ghergurovich, J.M.; Morscher, R.J.; Jang, C.; Teng, X.; Lu, W.; Esparza, L.A.; Reya, T.; Le, Z.; Guo, J.Y.; et al. Glucose feeds the TCA cycle via circulating lactate. Nature 2017, 551, 115-118. [CrossRef] [PubMed]

104. Sellers, K.; Fox, M.P.; Bousamra, M., II; Slone, S.P.; Higashi, R.M.; Miller, D.M.; Wang, Y.; Yan, J.; Yuneva, M.O.; Deshpande, R.; et al. Pyruvate carboxylase is critical for non-small-cell lung cancer proliferation. J. Clin. Investig. 2015, 125, 687-698. [CrossRef] [PubMed]

105. Fan, T.W.; Lane, A.N.; Higashi, R.M.; Farag, M.A.; Gao, H.; Bousamra, M.; Miller, D.M. Altered regulation of metabolic pathways in human lung cancer discerned by (13)C stable isotope-resolved metabolomics (SIRM). Mol. Cancer 2009, 8, 41. [CrossRef] [PubMed]

106. Faubert, B.; Li, K.Y.; Cai, L.; Hensley, C.T.; Kim, J.; Zacharias, L.G.; Yang, C.; Do, Q.N.; Doucette, S.; Burguete, D.; et al. Lactate Metabolism in Human Lung Tumors. Cell 2017, 171, 358-371. [CrossRef] [PubMed]

107. Perera, R.M.; Stoykova, S.; Nicolay, B.N.; Ross, K.N.; Fitamant, J.; Boukhali, M.; Lengrand, J.; Deshpande, V.; Selig, M.K.; Ferrone, C.R.; et al. Transcriptional control of autophagy-lysosome function drives pancreatic cancer metabolism. Nature 2015, 524, 361-365. [CrossRef]

108. Karsli-Uzunbas, G.; Guo, J.Y.; Price, S.; Teng, X.; Laddha, S.V.; Khor, S.; Kalaany, N.Y.; Jacks, T.; Chan, C.S.; Rabinowitz, J.D.; et al. Autophagy is required for glucose homeostasis and lung tumor maintenance. Cancer Discov. 2014, 4, 914-927. [CrossRef]

109. Seo, J.W.; Choi, J.; Lee, S.Y.; Sung, S.; Yoo, H.J.; Kang, M.J.; Cheong, H.; Son, J. Autophagy is required for PDAC glutamine metabolism. Sci. Rep. 2016, 6, 37594. [CrossRef]

110. Tan, H.W.S.; Sim, A.Y.L.; Long, Y.C. Glutamine metabolism regulates autophagy-dependent mTORC1 reactivation during amino acid starvation. Nat. Commun. 2017, 8, 338. [CrossRef]

111. Onodera, J.; Ohsumi, Y. Autophagy is required for maintenance of amino acid levels and protein synthesis under nitrogen starvation. J. Biol. Chem. 2005, 280, 31582-31586. [CrossRef] [PubMed]

112. Guo, J.Y.; Teng, X.; Laddha, S.V.; Ma, S.; Van Nostrand, S.C.; Yang, Y.; Khor, S.; Chan, C.S.; Rabinowitz, J.D.; White, E. Autophagy provides metabolic substrates to maintain energy charge and nucleotide pools in Ras-driven lung cancer cells. Genes Dev. 2016, 30, 1704-1717. [CrossRef] [PubMed]

113. Elliott, I.A.; Dann, A.M.; Xu, S.; Kim, S.S.; Abt, E.R.; Kim, W.; Poddar, S.; Moore, A.; Zhou, L.; Williams, J.L.; et al. Lysosome inhibition sensitizes pancreatic cancer to replication stress by aspartate depletion. Proc. Natl. Acad. Sci. USA 2019, 116, 6842-6847. [CrossRef]

114. Saito, T.; Kuma, A.; Sugiura, Y.; Ichimura, Y.; Obata, M.; Kitamura, H.; Okuda, S.; Lee, H.C.; Ikeda, K.; Kanegae, Y.; et al. Autophagy regulates lipid metabolism through selective turnover of NCoR1. Nat. Commun. 2019, 10, 1567. [CrossRef]

115. Singh, R.; Kaushik, S.; Wang, Y.; Xiang, Y.; Novak, I.; Komatsu, M.; Tanaka, K.; Cuervo, A.M.; Czaja, M.J. Autophagy regulates lipid metabolism. Nature 2009, 458, 1131-1135. [CrossRef] [PubMed]

116. Goldsmith, J.; Levine, B.; Debnath, J. Autophagy and cancer metabolism. Methods Enzymol. 2014, 542, $25-57$. [CrossRef]

117. Yang, A.; Herter-Sprie, G.; Zhang, H.; Lin, E.Y.; Biancur, D.; Wang, X.; Deng, J.; Hai, J.; Yang, S.; Wong, K.K.; et al. Autophagy Sustains Pancreatic Cancer Growth through Both Cell-Autonomous and Nonautonomous Mechanisms. Cancer Discov. 2018, 8, 276-287. [CrossRef] [PubMed] 
118. Yang, A.; Rajeshkumar, N.V.; Wang, X.; Yabuuchi, S.; Alexander, B.M.; Chu, G.C.; Von Hoff, D.D.; Maitra, A.; Kimmelman, A.C. Autophagy is critical for pancreatic tumor growth and progression in tumors with p53 alterations. Cancer Discov. 2014, 4, 905-913. [CrossRef] [PubMed]

119. Boya, P.; Reggiori, F.; Codogno, P. Emerging regulation and functions of autophagy. Nat. Cell Biol. 2013, 15, 713-720. [CrossRef]

120. Sullivan, M.R.; Danai, L.V.; Lewis, C.A.; Chan, S.H.; Gui, D.Y.; Kunchok, T.; Dennstedt, E.A.; Vander Heiden, M.G.; Muir, A. Quantification of microenvironmental metabolites in murine cancers reveals determinants of tumor nutrient availability. Elife 2019, 8, e44235. [CrossRef] [PubMed]

121. Kim, J.; Kim, Y.C.; Fang, C.; Russell, R.C.; Kim, J.H.; Fan, W.; Liu, R.; Zhong, Q.; Guan, K.L. Differential regulation of distinct Vps34 complexes by AMPK in nutrient stress and autophagy. Cell 2013, 152, 290-303. [CrossRef] [PubMed]

122. Williams, T.; Forsberg, L.J.; Viollet, B.; Brenman, J.E. Basal autophagy induction without AMP-activated protein kinase under low glucose conditions. Autophagy 2009, 5, 1155-1165. [CrossRef] [PubMed]

123. Kon, M.; Kiffin, R.; Koga, H.; Chapochnick, J.; Macian, F.; Varticovski, L.; Cuervo, A.M. Chaperone-mediated autophagy is required for tumor growth. Sci. Transl. Med. 2011, 3, 109ra117. [CrossRef]

124. Lock, R.; Roy, S.; Kenific, C.M.; Su, J.S.; Salas, E.; Ronen, S.M.; Debnath, J. Autophagy facilitates glycolysis during Ras-mediated oncogenic transformation. Mol. Biol. Cell 2011, 22, 165-178. [CrossRef] [PubMed]

125. Lee, S.-W.; Zhang, Y.; Jung, M.; Cruz, N.; Alas, B.; Commisso, C. EGFR-Pak Signaling Selectively Regulates Glutamine Deprivation-Induced Macropinocytosis. Dev. Cell 2019, 50, 381-392. [CrossRef] [PubMed]

126. Davidson, S.M.; Jonas, O.; Keibler, M.A.; Hou, H.W.; Luengo, A.; Mayers, J.R.; Wyckoff, J.; Del Rosario, A.M.; Whitman, M.; Chin, C.R.; et al. Direct evidence for cancer-cell-autonomous extracellular protein catabolism in pancreatic tumors. Nat. Med. 2017, 23, 235-241. [CrossRef]

127. Guillaumond, F.; Bidaut, G.; Ouaissi, M.; Servais, S.; Gouirand, V.; Olivares, O.; Lac, S.; Borge, L.; Roques, J.; Gayet, O.; et al. Cholesterol uptake disruption, in association with chemotherapy, is a promising combined metabolic therapy for pancreatic adenocarcinoma. Proc. Natl. Acad. Sci. USA 2015, 112, 2473-2478. [CrossRef]

128. Kamphorst, J.J.; Cross, J.R.; Fan, J.; de Stanchina, E.; Mathew, R.; White, E.P.; Thompson, C.B.; Rabinowitz, J.D. Hypoxic and Ras-transformed cells support growth by scavenging unsaturated fatty acids from lysophospholipids. Proc. Natl. Acad. Sci. USA 2013, 110, 8882-8887. [CrossRef]

129. Bailey, P.; Chang, D.K.; Nones, K.; Johns, A.L.; Patch, A.M.; Gingras, M.C.; Miller, D.K.; Christ, A.N.; Bruxner, T.J.; Quinn, M.C.; et al. Genomic analyses identify molecular subtypes of pancreatic cancer. Nature 2016, 531, 47-52. [CrossRef]

130. Cancer Genome Atlas Research Network. Integrated Genomic Characterization of Pancreatic Ductal Adenocarcinoma. Cancer Cell 2017, 32, 185-203. [CrossRef]

131. Collisson, E.A.; Sadanandam, A.; Olson, P.; Gibb, W.J.; Truitt, M.; Gu, S.; Cooc, J.; Weinkle, J.; Kim, G.E.; Jakkula, L.; et al. Subtypes of pancreatic ductal adenocarcinoma and their differing responses to therapy. Nat. Med. 2011, 17, 500-503. [CrossRef] [PubMed]

132. Moffitt, R.A.; Marayati, R.; Flate, E.L.; Volmar, K.E.; Loeza, S.G.; Hoadley, K.A.; Rashid, N.U.; Williams, L.A.; Eaton, S.C.; Chung, A.H.; et al. Virtual microdissection identifies distinct tumor- and stroma-specific subtypes of pancreatic ductal adenocarcinoma. Nat. Genet. 2015, 47, 1168-1178. [CrossRef] [PubMed]

133. Peng, J.; Sun, B.F.; Chen, C.Y.; Zhou, J.Y.; Chen, Y.S.; Chen, H.; Liu, L.; Huang, D.; Jiang, J.; Cui, G.S.; et al. Single-cell RNA-seq highlights intra-tumoral heterogeneity and malignant progression in pancreatic ductal adenocarcinoma. Cell Res. 2019, 29, 725-738. [CrossRef] [PubMed]

134. Elyada, E.; Bolisetty, M.; Laise, P.; Flynn, W.F.; Courtois, E.T.; Burkhart, R.A.; Teinor, J.A.; Belleau, P.; Biffi, G.; Lucito, M.S.; et al. Cross-Species Single-Cell Analysis of Pancreatic Ductal Adenocarcinoma Reveals Antigen-Presenting Cancer-Associated Fibroblasts. Cancer Discov. 2019, 9, 1102-1123. [CrossRef] [PubMed]

135. Sonveaux, P.; Vegran, F.; Schroeder, T.; Wergin, M.C.; Verrax, J.; Rabbani, Z.N.; De Saedeleer, C.J.; Kennedy, K.M.; Diepart, C.; Jordan, B.F.; et al. Targeting lactate-fueled respiration selectively kills hypoxic tumor cells in mice. J. Clin. Investig. 2008, 118, 3930-3942. [CrossRef] [PubMed]

136. Jimenez-Valerio, G.; Martinez-Lozano, M.; Bassani, N.; Vidal, A.; Ochoa-de-Olza, M.; Suarez, C.; Garcia-Del-Muro, X.; Carles, J.; Vinals, F.; Graupera, M.; et al. Resistance to Antiangiogenic Therapies by Metabolic Symbiosis in Renal Cell Carcinoma PDX Models and Patients. Cell Rep. 2016, 15, 1134-1143. [CrossRef] [PubMed] 
137. Pisarsky, L.; Bill, R.; Fagiani, E.; Dimeloe, S.; Goosen, R.W.; Hagmann, J.; Hess, C.; Christofori, G. Targeting Metabolic Symbiosis to Overcome Resistance to Anti-angiogenic Therapy. Cell Rep. 2016, 15, 1161-1174. [CrossRef] [PubMed]

138. Allen, E.; Mieville, P.; Warren, C.M.; Saghafinia, S.; Li, L.; Peng, M.W.; Hanahan, D. Metabolic Symbiosis Enables Adaptive Resistance to Anti-angiogenic Therapy that Is Dependent on mTOR Signaling. Cell Rep. 2016, 15, 1144-1160. [CrossRef] [PubMed]

139. Hanahan, D.; Coussens, L.M. Accessories to the crime: Functions of cells recruited to the tumor microenvironment. Cancer Cell 2012, 21, 309-322. [CrossRef] [PubMed]

140. Lisanti, M.P.; Martinez-Outschoorn, U.E.; Sotgia, F. Oncogenes induce the cancer-associated fibroblast phenotype: Metabolic symbiosis and "fibroblast addiction" are new therapeutic targets for drug discovery. Cell Cycle 2013, 12, 2723-2732. [CrossRef] [PubMed]

141. Yang, L.; Achreja, A.; Yeung, T.L.; Mangala, L.S.; Jiang, D.; Han, C.; Baddour, J.; Marini, J.C.; Ni, J.; Nakahara, R.; et al. Targeting Stromal Glutamine Synthetase in Tumors Disrupts Tumor Microenvironment-Regulated Cancer Cell Growth. Cell Metab. 2016, 24, 685-700. [CrossRef] [PubMed]

142. Sherman, M.H.; Yu, R.T.; Tseng, T.W.; Sousa, C.M.; Liu, S.; Truitt, M.L.; He, N.; Ding, N.; Liddle, C.; Atkins, A.R.; et al. Stromal cues regulate the pancreatic cancer epigenome and metabolome. Proc. Natl. Acad. Sci. USA 2017, 114, 1129-1134. [CrossRef] [PubMed]

143. Olivares, O.; Mayers, J.R.; Gouirand, V.; Torrence, M.E.; Gicquel, T.; Borge, L.; Lac, S.; Roques, J.; Lavaut, M.N.; Berthezene, P.; et al. Collagen-derived proline promotes pancreatic ductal adenocarcinoma cell survival under nutrient limited conditions. Nat. Commun. 2017, 8, 16031. [CrossRef] [PubMed]

144. Husain, Z.; Huang, Y.; Seth, P.; Sukhatme, V.P. Tumor-derived lactate modifies antitumor immune response: Effect on myeloid-derived suppressor cells and NK cells. J. Immunol. 2013, 191, 1486-1495. [CrossRef] [PubMed]

145. Hutcheson, J.; Balaji, U.; Porembka, M.R.; Wachsmann, M.B.; McCue, P.A.; Knudsen, E.S.; Witkiewicz, A.K. Immunologic and Metabolic Features of Pancreatic Ductal Adenocarcinoma Define Prognostic Subtypes of Disease. Clin. Cancer Res. 2016, 22, 3606-3617. [CrossRef] [PubMed]

146. Li, D. Diabetes and pancreatic cancer. Mol. Carcinog. 2012, 51, 64-74. [CrossRef] [PubMed]

147. Andersen, D.K.; Korc, M.; Petersen, G.M.; Eibl, G.; Li, D.; Rickels, M.R.; Chari, S.T.; Abbruzzese, J.L. Diabetes, Pancreatogenic Diabetes, and Pancreatic Cancer. Diabetes 2017, 66, 1103-1110. [CrossRef]

148. Ito, M.; Makino, N.; Matsuda, A.; Ikeda, Y.; Kakizaki, Y.; Saito, Y.; Ueno, Y.; Kawata, S. High Glucose Accelerates Cell Proliferation and Increases the Secretion and mRNA Expression of Osteopontin in Human Pancreatic Duct Epithelial Cells. Int. J. Mol. Sci. 2017, 18, 807. [CrossRef]

149. Han, L.; Ma, Q.; Li, J.; Liu, H.; Li, W.; Ma, G.; Xu, Q.; Zhou, S.; Wu, E. High glucose promotes pancreatic cancer cell proliferation via the induction of EGF expression and transactivation of EGFR. PLoS ONE 2011, 6, e27074. [CrossRef]

150. Rahn, S.; Zimmermann, V.; Viol, F.; Knaack, H.; Stemmer, K.; Peters, L.; Lenk, L.; Ungefroren, H.; Saur, D.; Schafer, H.; et al. Diabetes as risk factor for pancreatic cancer: Hyperglycemia promotes epithelial-mesenchymal-transition and stem cell properties in pancreatic ductal epithelial cells. Cancer Lett. 2018, 415, 129-150. [CrossRef]

151. Jian, Z.; Cheng, T.; Zhang, Z.; Raulefs, S.; Shi, K.; Steiger, K.; Maeritz, N.; Kleigrewe, K.; Hofmann, T.; Benitz, S.; et al. Glycemic Variability Promotes Both Local Invasion and Metastatic Colonization by Pancreatic Ductal Adenocarcinoma. Cell Mol. Gastroenterol. Hepatol. 2018, 6, 429-449. [CrossRef] [PubMed]

152. Stolzenberg-Solomon, R.Z.; Graubard, B.I.; Chari, S.; Limburg, P.; Taylor, P.R.; Virtamo, J.; Albanes, D. Insulin, glucose, insulin resistance, and pancreatic cancer in male smokers. JAMA 2005, 294, 2872-2878. [CrossRef] [PubMed]

153. Hu, C.M.; Tien, S.C.; Hsieh, P.K.; Jeng, Y.M.; Chang, M.C.; Chang, Y.T.; Chen, Y.J.; Chen, Y.J.; Lee, E.Y.P.; Lee, W.H. High Glucose Triggers Nucleotide Imbalance through O-GlcNAcylation of Key Enzymes and Induces KRAS Mutation in Pancreatic Cells. Cell Metab. 2019, 29, 1334-1349. [CrossRef] [PubMed]

154. Philip, B.; Roland, C.L.; Daniluk, J.; Liu, Y.; Chatterjee, D.; Gomez, S.B.; Ji, B.; Huang, H.; Wang, H.; Fleming, J.B.; et al. A high-fat diet activates oncogenic Kras and COX2 to induce development of pancreatic ductal adenocarcinoma in mice. Gastroenterology 2013, 145, 1449-1458. [CrossRef] [PubMed] 
155. Khasawneh, J.; Schulz, M.D.; Walch, A.; Rozman, J.; Hrabe de Angelis, M.; Klingenspor, M.; Buck, A.; Schwaiger, M.; Saur, D.; Schmid, R.M.; et al. Inflammation and mitochondrial fatty acid beta-oxidation link obesity to early tumor promotion. Proc. Natl. Acad. Sci. USA 2009, 106, 3354-3359. [CrossRef] [PubMed]

156. Sah, R.P.; Nagpal, S.J.; Mukhopadhyay, D.; Chari, S.T. New insights into pancreatic cancer-induced paraneoplastic diabetes. Nat. Rev. Gastroenterol. Hepatol. 2013, 10, 423-433. [CrossRef] [PubMed]

157. American Diabetes, A. Diagnosis and classification of diabetes mellitus. Diabetes Care 2010, 33, S62-S69. [CrossRef] [PubMed]

158. Sharma, A.; Smyrk, T.C.; Levy, M.J.; Topazian, M.A.; Chari, S.T. Fasting Blood Glucose Levels Provide Estimate of Duration and Progression of Pancreatic Cancer Before Diagnosis. Gastroenterology 2018, 155, 490-500. [CrossRef]

159. Desai, D.; Rao, D.; Sukrithan, V.; Weinstein, E.; Goyal, A.; Schubart, U. Pancreatic Cancer Heralded by Worsening Glycemic Control: A Report of Two Cases. J. Investig. Med. High Impact Case Rep. 2017, 5, 2324709617714286. [CrossRef]

160. Madiraju, A.K.; Erion, D.M.; Rahimi, Y.; Zhang, X.M.; Braddock, D.T.; Albright, R.A.; Prigaro, B.J.; Wood, J.L.; Bhanot, S.; MacDonald, M.J.; et al. Metformin suppresses gluconeogenesis by inhibiting mitochondrial glycerophosphate dehydrogenase. Nature 2014, 510, 542-546. [CrossRef]

161. Wheaton, W.W.; Weinberg, S.E.; Hamanaka, R.B.; Soberanes, S.; Sullivan, L.B.; Anso, E.; Glasauer, A.; Dufour, E.; Mutlu, G.M.; Budigner, G.S.; et al. Metformin inhibits mitochondrial complex I of cancer cells to reduce tumorigenesis. Elife 2014, 3, e02242. [CrossRef] [PubMed]

162. Amin, S.; Mhango, G.; Lin, J.; Aronson, A.; Wisnivesky, J.; Boffetta, P.; Lucas, A.L. Metformin Improves Survival in Patients with Pancreatic Ductal Adenocarcinoma and Pre-Existing Diabetes: A Propensity Score Analysis. Am. J. Gastroenterol. 2016, 111, 1350-1357. [CrossRef] [PubMed]

163. Sadeghi, N.; Abbruzzese, J.L.; Yeung, S.C.; Hassan, M.; Li, D. Metformin use is associated with better survival of diabetic patients with pancreatic cancer. Clin. Cancer Res. 2012, 18, 2905-2912. [CrossRef] [PubMed]

164. Li, D.; Yeung, S.C.; Hassan, M.M.; Konopleva, M.; Abbruzzese, J.L. Antidiabetic therapies affect risk of pancreatic cancer. Gastroenterology 2009, 137, 482-488. [CrossRef] [PubMed]

165. Chaiteerakij, R.; Petersen, G.M.; Bamlet, W.R.; Chaffee, K.G.; Zhen, D.B.; Burch, P.A.; Leof, E.R.; Roberts, L.R.; Oberg, A.L. Metformin Use and Survival of Patients With Pancreatic Cancer: A Cautionary Lesson. J. Clin. Oncol. 2016, 34, 1898-1904. [CrossRef] 